\title{
SISTEMA NACIONAL DE EDUCAÇÃO E PLANO NACIONAL DE EDUCAÇÃO: SIGNIFICADO, CONTROVÉRSIAS E PERSPECTIVAS
}

\author{
Rosemary Mattos* \\ Selma Venco ${ }^{* *}$
}

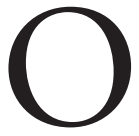

Professor Dermeval Saviani dispensa apresentações e iça novamente suas bandeiras em defesa da educação pública na atinente publicação Sistema Nacional de Educação $e$ Plano Nacional de Educação: significado, controvérsias e perspectivas ${ }^{1}$, em momento particular de aprovação do Plano Nacional de Educação 2014-2024 (PNE) e de elaboração dos Estaduais e Municipais.

A obra, organizada em sete capítulos, acompanha um suplemento com texto integral do Plano Nacional de Educação (PNE), que conduz o leitor à reflexão acerca do significado, as controvérsias e as perspectivas do Plano para a próxima década.

Saviani permanece fiel à matriz teórica que marca o conjunto de sua obra acadêmica e apresenta ao leitor a concretizaçáo de um pensar de tal forma convincente e coerente que dificultará a batalha dos que apostam na hierarquização entre iguais.

\footnotetext{
* Rede Pública de Ensino do Estado de São Paulo, Estiva Gerbi, SP., Brasil. E-mail de contato: rosemattos09@hotmail.com

** Universidade Estadual de Campinas, Faculdade de Educação (Unicamp/FE), Campinas, SP., Brasil. E-mail de contato: selma.venco@gmail.com
} 
A partir da síntese elaborada por Marx de que o homem transforma a natureza e nesse processo ele próprio se transforma, o autor aplicará essa lógica a fim de desnaturalizar processos, muitas vezes, tão enraizados que podem ocultar o fato de que se trata de um processo humano. Essa perspectiva é remetida à conceituação de sistema, uma vez que ele é fruto da ação humana e, portanto, uma construção social.

Seu ponto de partida é, portanto, problematizar o conceito de sistema e, por conseguinte, o de sistema nacional de educação. Para tanto, opta por interessante estratégia didática, a qual remete o leitor, em primeiro lugar, a refletir sobre o processo de desnaturalização dos fatos, uma vez que, para ele, a existência humana é pautada pelo trinômio situação-liberdade-consciência, ressaltando, assim, a intencionalidade presente no ato de sistematizar.

Enfrenta, mais uma vez, o desafio de problematizar o clássico embate sobre sistema e seus significados, o qual, para Saviani, ultrapassa as barreiras etimológicas e abaliza ponderaçôes de caráter epistemológico as quais persegue desde 1968. Para ele o conceito de sistema refere-se à "[...] unidade de vários elementos intencionalmente reunidos de modo que forme um conjunto coerente e operante [...]” (p. 4). Essa acepção será cotejada à de estrutura que é por ele definida como o "[...] conjunto de elementos; por isso, muitas vezes, ambos são usados como sinônimos [...]" (p. 5).

Enfatiza a importância da coerência interna e externa da ação sistematizadora por meio da articulação do plano concreto e as construçôes teóricas, com fundamento em objetivos coletivos. Dessa forma, para o autor, o sistema origina-se de um problema concreto consciente, na busca de caminhos para superação deste.

Apresenta, portanto, a distinção entre os termos estrutura, entendido como a própria textura da realidade; e sistema, como uma ordem que o homem impóe à realidade (p. 9). Alerta para os aspectos ideológicos presentes em certos termos que passam a ser usados com equivalência, mas que, de fato, se inscrevem em lógica, comumente, em uma perspectiva política distinta. Exemplifica por meio da própria mercantilização da educação que utiliza, para a venda de produtos e em seus slogans, o termo "sistema de ensino". Seu posicionamento é contundente 
em defesa da ideia de que o sistema de ensino só pode ser público, posto que apenas o Estado tem legitimidade para legislar sobre a educação.

Tais perspectivas alçadas à compreensão do sistema educacional implica na relação entre a teoria e a prática, concretizada na práxis educativa, posto que para se refletir sobre a educação sistematizada é indispensável o movimento ininterrupto dialético da ação-reflexão-açâo (p. 12). Esse movimento é, para Saviani, dialético da atividade educativa, a qual é intencional para ação coletiva.

A partir dessas precisóes convida o leitor a compreender a construçãoo histórica que envolve a sistematização das instituiçôes escolares, a qual estabelece estreita relação com as transformações na sociedade e as injunçôes para seu delineamento.

Neste sentido, são muitos os desafios enfrentados para a constituição de um sistema de ensino e Saviani elege como palavra-chave, para caracterizar a política educacional: a descontinuidade. Os caminhos tortuosos e pendulares traçados pela política educacional, que obstaculizam a construção do sistema nacional de educação, são pelo autor destacados e demonstra o caráter pendular das reformas que oscilam entre centralização e descentralização das políticas.

Essa peculiaridade histórica da política brasileira é igualmente marcada por avanços e retrocessos, na medida em que os elaboradores buscam imprimir as marcas das influências que sofrem, nas quais prevalecem os interesses privados travestidos de interesse público.

Contribui para a não constituição e/ou fortalecimento do SNE o tímido financiamento que marca sua história desde a invasão portuguesa. Não obstante, o autor reconheça a ampliaçáo paulatina dos percentuais de arrecadação destinados à educação, estes são considerados, por Saviani, como ainda insuficientes para fazer frente às reais e crescentes demandas a serem enfrentadas, ainda que a Constituição Federal de 1988, art. 60, em suas disposiçôes transitórias, previsse a destinação à educação de ao menos $50 \%$ dos impostos da União, Estados e Distrito Federal e Municípios no prazo de 10 anos, com vistas à erradicação do analfabetismo e ao atendimento escolar. 
Tais opções fizeram com que o Brasil ainda apresente índice de analfabetismo importante e retardatário em relação à América Latina desde o século XIX

Constata que a política educacional brasileira foi, e permanece sendo, marcada por quatro dimensóes, quais sejam: filantropia, representada pelo Estado Mínimo, que reconhece a educação como direito de todos, mas não assumido pelo poder público e sim imputando-a à sociedade; protelação, caracterizada pela ausência de enfrentamento adequado dos problemas a serem solucionados; fragmentação, marcada pela falta de unidade, já preconizada no Manifesto de 1932 pelo destaque: “[...] todos os nossos esforços, sem unidade de plano e sem espírito de continuidade não lograram ainda criar um sistema de organizaçẫo escolar [...]” (p. 38); e, por fim, a improvisação, destacada pela permanente desconstrução legal dos aspectos fundamentais para a edificação do SNE. Essa somatória de aspectos elencados pelo autor resulta na degradação da educação pública expressa na teia dos baixos salários, das péssimas condiçóes de trabalho, pela avaliação de resultados capitaneada por orientaçóes internacionais que adestram crianças e tentam capturar a autonomia docente, por meio da prescrição do trabalho intelectual.

A partir desse quadro analítico, Saviani retoma os indicativos que configuram a construção e a concretização de um Sistema Nacional de Ensino, lembrando que a intencionalidade para sua criação está presente no Brasil desde o Império. Contudo, a educação só foi tratada como nacional em 1930.

Define, portanto, que Sistema Nacional de Educação é:

[...] a unidade dos vários aspectos ou serviços educacionais mobilizados por determinado país, intencionalmente reunidos de modo que formem um conjunto coerente que opera eficazmente no processo de educação da população. (p. 51)

Saviani indaga: a articulação entre os entes federados lograria um Sistema Nacional de Educação? A construção dos argumentos leva à reflexão acerca da estruturação legal da educação que imputa à União 
regulamentar a educação nacional por meio da Lei de Diretrizes e Bases a qual, por sua vez, confere grau de autonomia a estados e municípios. Os municípios teriam, portanto, liberdade para contemplar suas diversidades ou haveria, de fato, a mutação da diversidade em desigualdade? Contrário à municipalização, Saviani constata que os municípios pobres fatalmente terão um ensino empobrecido e, nutriria, portanto, a agudização das desigualdades sociais. Para ele, é essencial ir além do respeito às diversidades regionais e compreender o município como parte do todo, cuja articulação é imperativa para o fortalecimento do sistema educacional.

As consideraçóes traçadas por Saviani reafirmam seu posicionamento em defesa da educação pública, tendo o Estado como seu guardião. Rever a representação nos Conselhos e as formas de financiamento, bem como repensar o currículo escolar na hora de abordar o trabalho como princípio educativo distanciando-se dos adestramentos praticados atendendo interesses do setor privado, a valorização da carreira docente e o fim da mercantilização do ensino se configuram como alguns dos importantes desafios a serem enfrentados na elaboração e concretização dos Planos de Educaçáo.

A despeito dos entraves é importante reconhecer que a elaboraçáo do PNE, desde 2010, representa um momento democrático e de luta dos envolvidos com a educação, mesmo que ainda distante dos anseios da sociedade. $\mathrm{O}$ maior desafio inicia-se a partir de sua aprovação, no acompanhamento, avaliação e proposição de sua implementação e no processo contínuo de ação-reflexão-ação.

\section{NOTAS}

1. SAVIANI, D. Sistema Nacional de Educação e Plano Nacional de Educação: significado, controvérsias e perspectivas. Campinas, SP: Autores Associados, 2014.

Recebido em 01 de junho de 2015.

Aprovado em 15 de setembro de 2015.

DOI: http://dx.doi.org/10.1590/CC0101-32622015150383 